\title{
Smart Growth and Transit- Oriented Development at the State Level: Lessons from California, New Jersey, and Western Australia
}

\author{
John L. Renne, University of New Orleans
}

\begin{abstract}
The states of California, New Jersey, and Western Australia encourage smart growth through the employment of transit-oriented development (TOD). This article documents each state's approach and highlights the importance of interagency cooperation at the state-level and intergovernmental cooperation between state and local governments. This article discusses the importance of state government participation in the planning and creation of policy to facilitate TOD and recommends elements for a model state TOD program.
\end{abstract}

\section{Introduction}

Transit-oriented development (TOD) - compact, mixed-use, and pedestrianfriendly precincts around transit stations-is an increasingly popular strategy for encouraging smart growth in both Australia and the United States. California, New Jersey, and Western Australia have implemented policies and programs that facilitate intra- and intergovernmental cooperation to promote TODs. This article 
describes the policies in each state and discusses the importance of state government leadership for promoting smart growth and creating TODs.

\section{Similarities and Differences Between California, New Jersey, and Western Australia}

A comparison between planning in different states within America and between the United States and Australia must acknowledge both similarities and differences. The state government of Western Australia is based on the parliamentary system unlike the state governments of California and New Jersey. While this structural difference may seem significant, transportation planning decisions in both Australia and the United States are typically determined by bureaucrats working for state transportation departments in ccordination with elected officials, while land-use decisions are made by local councils. Unlike state powers in America, the Western Australia Planning Commission (WAPC) has the right to override local land-use decisions, yet this power is seldom used because of a strong belief in local decision making. An example of this is a recent proposal to build a TOD on state- owned property in Claremont, Western Australia. The Public Transport Authority (PTA), a state agency, spent years planning a mixed-use TOD adjacent to a rail station on the agency's property. A local election resulted in a town council that opposed the project. In the face of PTA's intentions to push the project along, the Minister for Planning and Infrastructure and the WAPC would not overrule the local decision. The PTA, despite being a state agency, was treated like any other private sector developer.

Tables 1 and 2 provide a comparison across each of these states and urban areas within the states. As shown in Table 1, California is the most populated state with 18 times as many people as Western Australia and 4 times as many people as New Jersey. It also has the largest rail network. The urban densities of major metropolitan statistical areas (MSAs) in California range from 3,369 people per square mile in San Diego to 4,717 people per square mile in the San Francisco MSA. The New York/Northern New Jersey MSA's urban population density is 4,203 people per square mile while Perth is the lowest with 2,754 people per square mile. Although Perth has the lowest population and employment densities accompanied by high levels of car ownership and use, it has a relatively high proportion of jobs in the central business district (CBD) and a relatively high proportion of public transport usage per capita on rail (as shown in Table 2). Western Australia's population is not likely to match either California or New Jersey, but as the city grows, current 

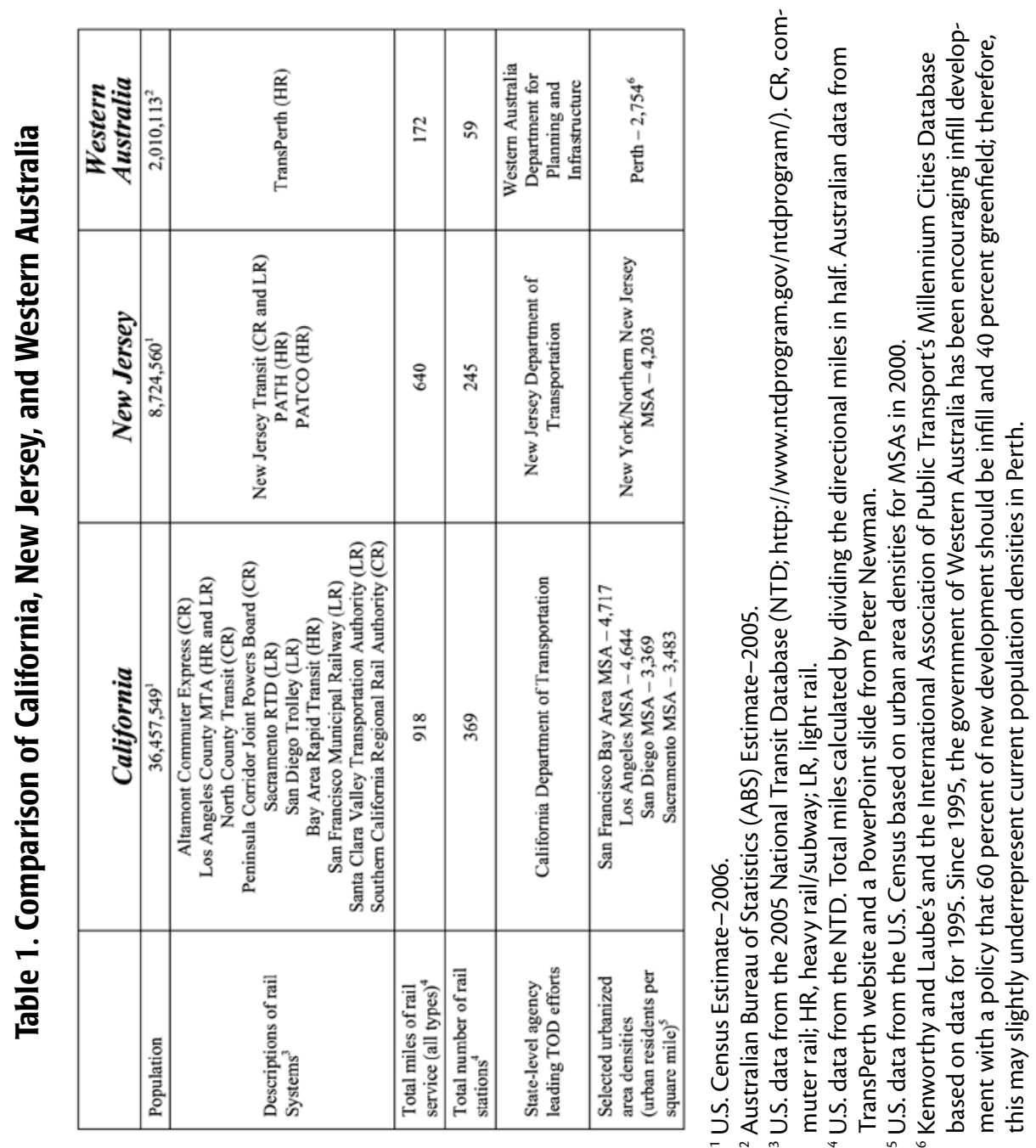


\section{Table 2. Comparison of Los Angeles, San Fransisco, San Diego, New York, and Perth}

\begin{tabular}{|c|c|c|c|c|c|c|}
\hline & & $\begin{array}{c}\text { Los } \\
\text { Angeles }\end{array}$ & $\begin{array}{c}\text { San } \\
\text { Francisco }\end{array}$ & San Diego & New York & Perth \\
\hline Urban density & persons/ha & 24.1 & 20.5 & 14.5 & 18.0 & 10.9 \\
\hline Job density & jobs/ha & 11.2 & 8.9 & 6.6 & 9.5 & 4.6 \\
\hline $\begin{array}{l}\text { Proportion of } \\
\text { jobs in CBD }\end{array}$ & $\%$ & $4.1 \%$ & $13.9 \%$ & $5.8 \%$ & $20.7 \%$ & $19.2 \%$ \\
\hline $\begin{array}{l}\text { Metropolitan } \\
\text { gross domestic } \\
\text { product per } \\
\text { capita }\end{array}$ & USD & $\$ 28,243$ & $\$ 37,154$ & $\$ 26,508$ & $\$ 34,395$ & $\$ 21,995$ \\
\hline $\begin{array}{l}\text { Length of road } \\
\text { per person }\end{array}$ & $\mathrm{m} /$ person & 3.7 & 4.5 & 5.3 & 4.9 & 9.1 \\
\hline $\begin{array}{l}\text { Parking spaces } \\
\text { per } 1,000 \text { CBD } \\
\text { jobs }\end{array}$ & $\begin{array}{c}\text { spaces/1,000 } \\
\text { jobs }\end{array}$ & 627 & 157 & 767 & 66 & 630 \\
\hline $\begin{array}{l}\text { Total length of } \\
\text { reserved public } \\
\text { transport routes } \\
\text { per } 1,000 \text { persons }\end{array}$ & $\mathrm{m} / 1,000$ persons & 39.5 & 53.1 & 44.9 & 92.4 & 82.0 \\
\hline $\begin{array}{l}\text { Passenger cars } \\
\text { per } 1,000 \text { persons }\end{array}$ & $\begin{array}{l}\text { units } / 1,000 \\
\text { persons }\end{array}$ & 527.4 & 599.6 & 555.1 & 444.0 & 658.1 \\
\hline $\begin{array}{l}\text { Daily public } \\
\text { transport trips } \\
\text { per capita }\end{array}$ & trips/person & 0.09 & 0.21 & 0.05 & 0.29 & 0.14 \\
\hline \multicolumn{7}{|c|}{ Mode split of all trips } \\
\hline $\begin{array}{l}\text { Nonmotorized } \\
\text { modes }\end{array}$ & $\%$ & $9.5 \%$ & $11.6 \%$ & $5.8 \%$ & $16.1 \%$ & $9.1 \%$ \\
\hline $\begin{array}{l}\text { Motorized public } \\
\text { modes }\end{array}$ & $\%$ & $2.3 \%$ & $5.4 \%$ & $1.5 \%$ & $8.6 \%$ & $3.7 \%$ \\
\hline $\begin{array}{l}\text { Motorized } \\
\text { private modes }\end{array}$ & $\%$ & $88.2 \%$ & $83.0 \%$ & $92.8 \%$ & $75.2 \%$ & $87.2 \%$ \\
\hline $\begin{array}{l}\text { Total public } \\
\text { transport } \\
\text { boardings per } \\
\text { capita }\end{array}$ & boardings/person & 49.1 & 93.6 & 27.0 & 131.5 & 59.5 \\
\hline
\end{tabular}

Source: Kenworthy and Laube's and the International Association of Public Transport's Millennium Cities database (data represents 1995).

policies favor infill development and TOD. What remains a major question in all three states is whether smart growth efforts will make a noticeable shift away from automobile-based sprawling development.

The dominance of automobiles, low-density suburbs, and segregated land uses is common across the three states. These three states have been chosen in this comparison due to the nature of their state-government led process to facilitate 
TOD. The departments of transportation in California and New Jersey and the Department for Planning and Infrastructure (DPI) ${ }^{1}$ began a cross-agency dialogue in the late 1990s/early 2000s to facilitate TOD planning and policy. This article summarizes policy and planning outcomes from each of these efforts.

\section{Smart Growth and TOD Planning at the State Level}

Urban rail is becoming a fashionable mobility alternative, especially in cities where no foreseeable solutions exist to paralyzing traffic congestion. The Economist reported that light rail ridership in the United States was up 11.2 percent from 2005 to 2006. Salt Lake City saw a growth in light rail ridership of 39 percent during the same period; trains are running overcapacity (All aboard! 2006). These trends, coupled with a growing market for New Urbanist neighborhoods, are making conditions ripe for TOD, although government regulations remain an obstacle. Levine (2006) argues that compact, mixed-use communities are illegal in most cities. Recent books, articles, and reports have focused on local and regional policies for facilitating TOD, but relatively few studies have looked at the role of the state government.

State TOD policy is critical because it can set a tone for regional and local policy. States have a vested interest in the success of TOD. According to the U.S. Census, in 2003-2004, state government spending accounted for 74 percent of capital expenditures on roads and highways. Perhaps more surprising, states picked up 28 percent of transit subsidies across the United States. In total, state government spent more than $\$ 1.2$ trillion on passenger transportation across the United States. The situation is similar in Australia where state governments pay for the majority of passenger transportation infrastructure and services (Bureau of Transport and Regional Economics 2003).

Developing a mixed-use, pedestrian-friendly precinct around train stations is not a new concept, but it is regaining popularity. Older cities in the United States and Australia first developed during the train and tram era, which took place from the 1860s until the proliferation of the automobile during the 20th century (Newman and Kenworthy 1999). Cities like Boston, Chicago, Melbourne, New York, Philadelphia, and Sydney still rely on the rail infrastructure created during that period. Today, older and newer cities alike in America and Australia are turning to transit and TOD as an alternative to sprawl, and as a way to encourage economic revitalization, community diversity, and travel alternatives. Transit-Oriented Development in America: Experiences, Challenges, and Prospects (Cervero et al. 2004) studied TODs across the United States to determine effective polices. This volumi- 
nous study reports on many public and private sector benefits of TOD. Under the right conditions, TODs yield higher shares of transit ridership compared to their surrounding regions (Cervero 1994; Lund, Cervero, and Wilson 2004; Renne 2005). They also lead to higher land values closer to rail stations (Cervero et al. 2004; California Department of Transportation 2002b). The New Transit Town: Best Practices in Transit-Oriented Development (Dittmar and Ohland 2004) provides case studies of how local and regional TOD policies have been instrumental across the United States. This book discusses key issues such as zoning, financing, and parking. The Urban Land Institute's Developing Around Transit (Dunphy et al. 2004) covers much of the same ground but is written partially to inform the development and transit industries about how to better plan and capitalize on TOD. Dunphy et al. (2004) recommend 10 principles for developing around transit:

1. Make it better with a vision.

2. Apply the power of partnerships.

3. Think development when thinking about transit.

4. Get the parking right.

5. Build a place, not a project.

6. Make retail development market driven, not transit driven.

7. Mix uses, but not necessarily in the same place.

8. Make buses a great idea.

9. Encourage every price point to live around transit.

10. Engage corporate attention.

A study funded by the U.S. Federal Transit Administration found that over the next 25 years, 14.6 million households, which represent one-quarter of all new households, could be looking for housing in TODs (Center for Transit Oriented Development 2004). Another study found market demand for compact, mixeduse communities between 10 to 33 percent of households across America (Levine and Inam 2004). The strong demand for the TOD lifestyle is perhaps an important reason that Emerging Trends in Real Estate rated TOD as the top real estate investment prospect in 2005 and 2006. Because of increasing demand, fueled by a demographic-shift that is favoring cities, land around train stations appreciates faster in growing markets and holds value in declining markets (Urban Land Institute and PricewaterhouseCoopers 2005 and 2006). 
When looking specifically at research focused on state governments and TOD policy, the literature is nascent. Transit-Oriented Development in America: Experiences, Challenges, and Prospects (Cervero et al. 2004) discusses a few state TOD policies within its case studies, but the focus of the report is on local and regional policies. States play an important role in financing strategic and station-area planning, infrastructure, and streetscape improvements. Other roles for state government include promoting regional planning and coordination across state agencies, setting goals to facilitate tax savings, encouraging environmental stewardship, creating funding programs and incentives, reducing regulatory and statutory barriers to land use, promoting public-private partnerships, and establishing pilot programs (Hersh 2001 cited in Cervero et al. 2004). Transit-Oriented Development in America found that four states have official TOD polices: California's Transit Village Development Planning Act, Oregon's Senate Bill 763 Vertical Housing Zone Bill, New Jersey Transit Village Initiative, and Maryland Transit Administration's program to fund TOD across the state. The Oregon bill authorizes tax abatements to infill medium- and high-density housing near rail stations. The Maryland Transit Administration provides substantial support for TOD, but despite being a state agency, it functions as a transit agency (Cervero et al. 2004).

Transit Villages in California: Progress, Prospects, and Policy Reforms (Cervero 1998) provides an analysis of state TOD policies in California. It summarizes interviews with planners into reasons the Transit Village Development Planning Act of 1994 failed to make much of an impact — the policy lacked funding and incentives for the application of Transit Village plans in California. As discussed below, California has taken strides to encourage TOD since this report, although funding remains a persistent problem.

The Role of State DOTs in Support of Transit-Oriented Development (Cambridge Systematics 2006) focuses specifically on state departments of transportation (DOTs). They found that DOTs in California, Florida, Maryland, Massachusetts, New Jersey, Pennsylvania, and Washington, D.C. are proactively involved with TOD, while DOTs in Colorado, Illinois, Minnesota, Oregon, and the State of Washington are implementing "other TOD-supportive activities." Not surprising, they found that many states have been reluctant to become involved with TOD because they view land-use planning as a function of local government, although as states increasingly become interested in smart growth, they are looking for ways to work in partnership with local governments on coordinating transportation and land-use policies. Louisiana, for example, is in the process of evaluating a new 
state planning office, which would seek to curb sprawl and promote infill development coordinated with transportation infrastructure.

A report by the American Planning Association (APA), Planning for Smart Growth: 2002 State of the States (Johnson et al., 2002), found that one-quarter of states in America had implemented moderate to substantial comprehensive planning reforms in support of smart growth. They also found bipartisan support, as smart growth executive orders issued from 1992-2001 were evenly divided between Republican and Democratic governors. Only 13 states have not attempted to encourage smart growth. The U.S. Environmental Protection Agency's (EPA) online database lists smart growth policies by state. This database includes local, regional, and state policies. Table 3 shows state governments that have adopted smart growth policies, by type, as reported by the U.S. EPA. ${ }^{2}$

\section{Table 3. State-Level Smart Growth Policies by State and Category as Reported by the U.S. EPA}

\begin{tabular}{|l|l|}
\hline \multicolumn{1}{|c|}{ Category of Smart Growth Policy ${ }^{1}$} & \multicolumn{1}{c|}{${\text { State Governments } \text { with } \text { Policies }^{2}}^{\text {Community and stakeholder }}$} \\
collaboration in development decisions & UT \\
\hline Compact building design & OR \\
\hline $\begin{array}{l}\text { Directs development toward existing } \\
\text { communities }\end{array}$ & IL, IN, MD, MI, NH, PA, WI \\
\hline Mixed land uses & CA \\
\hline Open space policies & $\begin{array}{l}\text { AZ, CA, DE, FL, GA, IL, MD, MT, NJ, } \\
\text { OR, WA }\end{array}$ \\
\hline $\begin{array}{l}\text { Predictable and cost-effective } \\
\text { development decisions }\end{array}$ & DE, IL \\
\hline Range of housing choices & MD, PA \\
\hline Variety of transportation choices & AZ, NC, NJ, OR, RI \\
\hline Walkable neighborhoods & CA, IL \\
\hline
\end{tabular}

Source: U.S. Environmental Protection Agency 2005.

1. Categories are defined by the U.S. EPA.

2. The comprehensiveness of the U.S. EPA database is questionable. Some states, such as New Jersey, have policies to promote compact building design, directing development toward existing communities, and policies in other categories, but they were not included in the U.S. EPA database.

According to the U.S. EPA, encouraging open space preservation is the most popular category of smart growth policy among state governments. Promoting development in existing communities also ranked high. This category is broadly defined and includes a variety of policies such as encouragement for civic buildings 
in cities and towns rather than in undeveloped areas. It also includes brownfield and greyfield cleanup. Promoting a variety of transportation choices was the third most frequently cited smart growth policy of state government.

Smart growth and TOD literature does not adequately address state TOD policies, most likely because of the topic's niche nature. While local and regional polices for encouraging TOD are paramount, state government has an important role in facilitating TOD both in Australia and the United States. State-level government in Australia typically engages more in land-use planning compared to American states, but both serve similar functions because ultimately local officials conduct land-use planning. The state's role in Australia is similar to the role of metropolitan planning organizations (MPOs) in the United States. In both countries the state and/or MPO is responsible for considering the long-range impacts of transportation infrastructure on land use. State government in both are responsible for the planning and implementation of transportation infrastructure, predominately highways. All American and Australian states have transportation departments that are responsible for spending millions on existing and new transportation infrastructure. States in both countries have regulatory agencies that deal with environmental, housing and finance, and economic development issues.

State-level land-use planning, including planning for TOD, is only conducted in a handful of states in America. California, Florida, Maryland, New Jersey, and Oregon, are five states that have the best-developed policies to constrain sprawl and encourage compact development in existing urban areas. In both Florida and Maryland, policies are broad and do not focus specifically on promoting TOD compared to California, New Jersey, and Oregon. In Australia, New South Wales, Queensland, South Australia, Victoria, and Western Australia all have a strategic policy for coordinating future development with rapid transit (Newman 2005) but Western Australia has established a special committee to encourage TOD. The next section summarizes polices in California, New Jersey, and Western Australia-three leaders in state-level TOD policy.

\section{California}

Population growth, traffic congestion, and expensive housing led to grassroots support for smart growth in California. The state has promoted the coordination of land use and transportation planning through several policies and programs (as shown in Table 4). The Community Based Transportation Planning grant program 
encourages compact and mixed-use development for projects that have a defined transportation objective, such as increasing transit ridership. The government also provides grants that reward communities that build housing and help reduce the jobs/housing imbalance. Localities receive bonuses when new units fulfill smart growth principles, such as being located in infill neighborhoods or close to retail and community services, or when units are affordable. The state provides technical planning assistance to encourage TOD and in some instances, the Department of Transportation (CalTrans) provides partial funding for parking structures in TODs. This has been important to free up surfacing parking to allow for a higher and better use of the land, including the construction of buildings near transit stations (as shown in Figures 1 and 2).

The Transit Village Development Planning Act of 1994 and Assembly Bill No. 1320 (passed in 2004) were intended to encourage TOD across the state. The earlier act allowed municipalities to create transit village plans around rail transit stations when they met a specific list of 13 public benefits. The act's revision in 2004 expanded transit village plans to any transit facility, including bus, rail, or ferry. Furthermore, it loosened the language of the previous act by stating that the plan must include only 5 of 13 "demonstrable public benefits." A study conducted in the late 1990s found few planners knew about the act because it really did not provide any financial benefits as the state had allocated insufficient funding to support transit village plans or construction (Cervero 1998). Tax increment financing (TIF) and land assemblage were originally part of the legislation but were removed before the bill's passage. Because of the state's rocky history with the misuse of redevelopment powers, legislators were hesitant to grant such powers to TODs unless they were within a blighted area, and in these situations, planners could rely on redevelopment law, thus leaving no need for a separate law for a transit village. ${ }^{3}$

A recent policy change by the State Treasurer's Office has led to more opportunities for affordable housing in TODs. Until recently, tax credits for affordable housing were distributed though a lottery system. Under a smart growth strategy called The Double Bottom Line: Investing in California's Emerging Markets (California State Treasurer 2001), the state began allocating tax credits on a point-based system. For developers to receive subsidies, they must choose sites close to transit, parks, and other amenities to receive the most points. An interview with Doug Shoemaker, deputy director of the Non-Profit Housing Association of Northern California (NPH), revealed his view on the program's success: 
I'd say that absent such a policy, the pattern would be more diffuse in that you'd still see 80 percent of the affordable multifamily housing as infill housing, but perhaps not as transit accessible. I think it's relatively easier for affordable housing to be financed as part of TODs in California as a result of these policies (Shoemaker 2004).

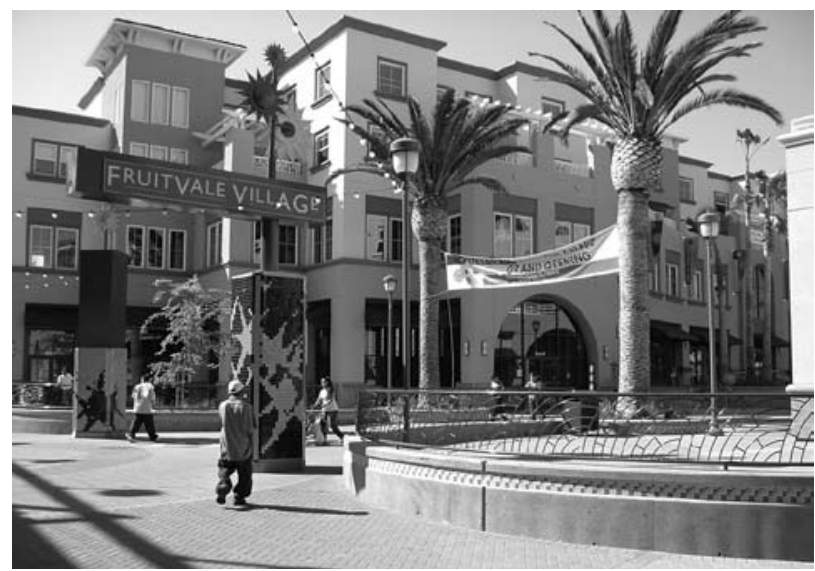

Figure 1. Compact Affordable Housing above Retail Next to the Train Station in Oakland's Fruitvale Transit Village

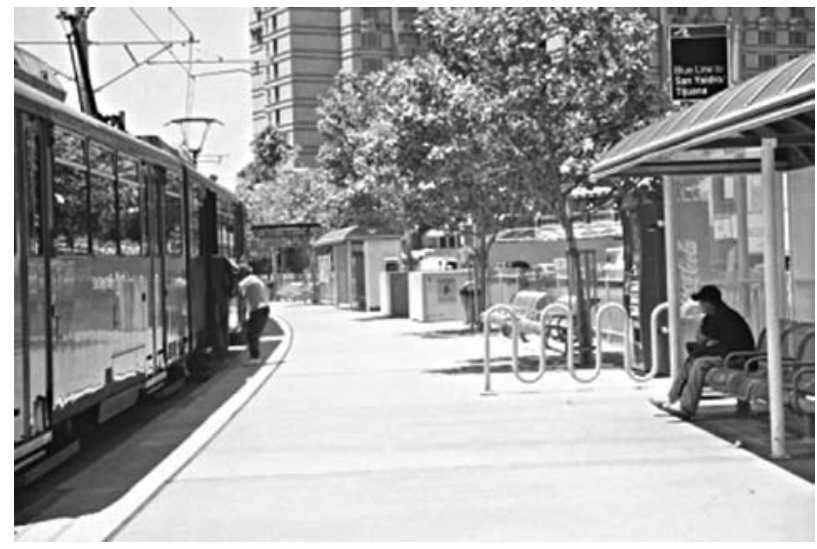

Figure 2. Hazard Center Station TOD in San Diego 
Other programs, such as the Cleanup Loans and Environmental Assistance to Neighborhoods (CLEAN) Program, Downtown Rebound Planning Grants Program, and the State Community Development Block Grant Program (CDBG) encourage infill development. While many of these programs are used outside of TODs, these policies have proved useful for encouraging TOD. Another example of a smart growth policy well suited to TODs has been the Safe Routes to Schools Program, which funds crosswalks, waking and bicycling paths, and traffic calming in neighborhoods with schools.

\section{Table 4. California's Smart Growth Policies}

\begin{tabular}{|l|l|}
\hline Policy/Program & Description \\
\hline $\begin{array}{l}\text { Community Based } \\
\text { (CBTP) grant program }\end{array}$ & $\begin{array}{l}\text { The CBTP program provides funds for } \\
\text { transportation/land-use planning projects that } \\
\text { support livable community concepts. Projects must } \\
\text { have a defined transportation objective and address } \\
\text { a deficiency, conflict, or opportunity in } \\
\text { coordinating land use and transportation planning. } \\
\text { Project proposals must include public participation } \\
\text { and must demonstrate the implementation of this } \\
\text { process throughout the project. }\end{array}$ \\
\hline $\begin{array}{l}\text { Reward to communities that } \\
\text { balance jobs and housing }\end{array}$ & $\begin{array}{l}\text { Grants are awarded to localities that have } \\
\text { succeeded in creating new housing in communities } \\
\text { with surplus jobs. In addition to the production of } \\
\text { new housing, the program also evaluates the quality } \\
\text { of housing in promoting "livable community } \\
\text { objectives" such as housing units within walking } \\
\text { distance to retail and community services. Bonuses } \\
\text { are given for infill projects and affordable units. } \\
\text { Communities are allowed to use the grants for a } \\
\text { wide range of community projects. }\end{array}$ \\
\hline $\begin{array}{l}\text { Support local efforts to plan } \\
\text { for TOD }\end{array}$ & $\begin{array}{l}\text { Incentives are provided to cities and counties that } \\
\text { establish transit village development districts that } \\
\text { link mixed-use developments to transit systems. } \\
\text { Development districts are located within one- } \\
\text { quarter mile radius of transit stations and may be } \\
\text { eligible for } 25 \text { percent density bonuses over } \\
\text { existing zoning regulations. Priority funding for } \\
\text { transportation improvements is given to localities } \\
\text { that plan to promote objectives of TOD. } \\
\text { Developments consistent with goals are given } \\
\text { expedited review. }\end{array}$ \\
\hline
\end{tabular}




\section{Table 4. California's Smart Growth Policies (cont'd.)}

\begin{tabular}{|c|c|}
\hline Policy/Program & Description \\
\hline Affordable housing tax credits & $\begin{array}{l}\text { The State Treasure's Office recently changed the } \\
\text { system of allocating affordable housing tax credits } \\
\text { from a lottery to a point-based system, in which } \\
\text { points are gained for being located near transit, } \\
\text { parks, town centers, and other amenities. Because } \\
\text { transit is worth so many points, affordable housing } \\
\text { must be located within walking distance to get the } \\
\text { subsidy. }\end{array}$ \\
\hline $\begin{array}{l}\text { Cleanup Loans and } \\
\text { Environmental Assistance to } \\
\text { Neighborhoods (CLEAN) } \\
\text { Program }\end{array}$ & $\begin{array}{l}\text { The CLEAN revolving loan fund was established } \\
\text { to encourage development in distressed areas of the } \\
\text { state by providing financing for environmental site } \\
\text { assessments and environmental cleanup actions on } \\
\text { urban brownfields and underutilized properties. }\end{array}$ \\
\hline $\begin{array}{l}\text { Downtown Rebound Planning } \\
\text { Grants Program }\end{array}$ & $\begin{array}{l}\text { This program funds local planning for infill } \\
\text { housing, adaptive reuse (conversion) of commercial } \\
\text { and industrial space into residential, and the } \\
\text { development of other forms of high-density } \\
\text { downtown housing. }\end{array}$ \\
\hline $\begin{array}{l}\text { State Community } \\
\text { Development Block Grant } \\
\text { Program (CDBG) }\end{array}$ & $\begin{array}{l}\text { The Department of Housing and Community } \\
\text { Development extends the federal Community } \\
\text { Development Block Grant program benefits to } \\
\text { nonentitlement cities and counties for housing } \\
\text { rehabilitation, infrastructure, community facilities, } \\
\text { economic development, and planning studies. }\end{array}$ \\
\hline Safe Routes to Schools & $\begin{array}{l}\text { Passed in 1999, the Safe Routes to School Bill } \\
\text { redirects some of the state's federal transportation } \\
\text { dollars to local governments for the purpose of } \\
\text { building crosswalks, pedestrian and bicycle paths, } \\
\text { sidewalks in neighborhoods where none exist, and } \\
\text { traffic calming in neighborhoods near schools to } \\
\text { slow vehicular traffic and encourage walking and } \\
\text { bicycling. }\end{array}$ \\
\hline Executive Order D-46-01 & $\begin{array}{l}\text { This order directs the California Department of } \\
\text { General Services to promote downtown } \\
\text { revitalization by constructing and reusing state } \\
\text { buildings in downtown and central city areas. }\end{array}$ \\
\hline
\end{tabular}

Source: California Department of Transportation 2002b; Johnson et al. 2002; U.S. Environmental Protection Agency 2005.

\section{California's Statewide TOD Study}

The Statewide Transit-Oriented Development Study: Factors for Success in California (California Department of Transportation, 2002a) recommended promoting TOD based on a variety of public benefits. The report found that TOD may reduce the 
rate of increase in vehicle miles traveled (VMTs) and increase households' disposable income due to lower rates of automobile ownership and use. TODs could also lead to less air pollution and energy consumption, spur economic development, contribute to more affordable housing, and decrease infrastructure expenditures (California Department of Transportation 2002a). The report concluded by recommending 14 strategies at the state policy level. These strategies are categorized into two main areas: (1) state policies and programs and (2) state funding for TOD planning and implementation. Table 5 lists the specific recommendations for each area.

Table 5. Specific Recommendations from California's Statewide TOD Study

\author{
1. State Policies and Programs \\ Strategy $1 \mathrm{~A} \quad$ Improve coordination of local and regional land use and transportation \\ planning \\ Strategy 1B Use and sale of state land for TOD \\ Strategy $1 C \quad$ Facilitate local review and approval processes \\ Strategy $1 C(1) \quad$ Coordinate a study of California Environmental Quality Act \\ (CEQA) processes in relation to TOD \\ Strategy $1 \mathrm{C}(2)$ Improve models and analysis tools \\ Strategy 1C(3) Improve data of effects and benefits of TOD \\ Strategy 1D Technical assistance and information
}

\title{
2. State Funding for TOD Planning and Implementation
}
Strategy $2 \mathrm{~A}$
Provide funding to local agencies to plan and implement TOD near major transit stations
Strategy 2A(1) Funding for local TOD planning
Strategy $2 \mathrm{~A}(2) \quad$ Funding for local agency TOD implementation
Strategy $2 \mathrm{~A}(3) \quad$ Funding for TOD demonstration projects
Strategy $2 A(4) \quad$ State Housing Incentive Program
Strategy 2B Targeted tax-increment financing for TOD
Strategy $2 \mathrm{C} \quad$ Financing for private sector development
Strategy 2D Use of state transportation funds for TOD
Strategy $2 \mathrm{E} \quad$ Expand Location Efficient Mortgage ${ }^{\mathrm{a}}$ Program

Source: California Department of Transportation 2002a, pp. 153-154.

a Location efficient mortgage programs allow homebuyers near transit stations to take on larger than conventional mortgages due to lower household transportation expenditures.

\section{Local and Regional Smart Growth and TOD Policy in California}

Although the focus of this article is on state TOD policy, local policies are also important for TOD implementation. Attention to TOD by the state government 
in California has created a signal to local government and MPOs that they too should be working to better integrate land uses around transit stations.

Local and regional policies in California were the subject of two chapters (one each for Northern and Southern California) in Transit-Oriented Development in the United States: Experiences, Challenges, and Prospects (Cervero et al. 2004). While many programs and policies were discussed, probably one of the most successful was the Bay Area's Transportation for Livable Communities (TLC) program. Operated by the Metropolitan Transportation Commission (MTC), the region's MPO, TLC plans to fund approximately $\$ 72$ million in 2007-2009 for smart growth projects, including TOD (Metropolitan Transportation Commission 2004). Part of TLC, the Housing Incentive Program (HIP), subsidizes both compact and affordable housing in TODs. HIP promotes residential density near transit stations and grants subsidies to cities and/or counties ranging from $\$ 1,000$ to $\$ 2,000$ per bedroom - the denser the project, the higher the subsidy. Affordable units also receive a $\$ 500$ bonus per bedroom (Cervero et al. 2004). The program has encouraged pedestrian-friendly and transit-oriented design by requiring that site plans include a sidewalk from the center of the development to the transit stop. Moreover, the subsidies have mandated that the development must be within one-third of a mile to a major transit station. According to the MTC, the HIP was established in late 2000 to address two of the Bay Area's biggest problems-traffic and housing shortages. From 2001 to 2004, the MTC set aside $\$ 9$ million for the HIP (Cervero et al. 2004).

In addition to the MTC, the Bay Area Association of Governments (ABAG) and the Bay Area Rapid Transit District (BART) have been active supporters of smart growth and TOD. In 2003, BART released Transit-Oriented Development Guidelines, which aimed to promote TOD along the Bay Area's regional commuter rail lines. The guidelines have helped educate planners, local officials, and developers about the importance of quality site design and how to address issues associated with parking in TODs.

In San Diego, support for smart growth and TOD has been strong. A chapter in The New Transit Town: Best Practices in Transit-Oriented Development (Dittmar and Ohland 2004) illustrates the success of San Diego's Barrio Logan's Mercado Project. The study described San Diego's widespread support for TOD, which was one of the first cities in the United States to adopt TOD design guidelines in the early 1990s. Successful TODs in the region have resulted from cooperation between 
the City and County of San Diego, the Metropolitan Transit Development Board (MTDB), and the San Diego Association of Governments (SANDAG).

Even Los Angeles, which most people associate with highways and sprawl, has made strides toward smart growth and TOD. While some may view Los Angeles's success with TOD as mixed, regional and local cooperation may promulgate a number of successful TODs in the future. The Southern California Association of Governments, Los Angeles's MPO, has worked closely with the County of Los Angeles's Regional Planning Department to prepare livable community and smart growth guidelines. The failure of some stations to implement a TOD may result from MTA's $^{4}$ decision to build the Blue Line along a corridor where land was inexpensive due to economic stagnation and an auto-dominated landscape. ${ }^{5}$ According to Cervero et al., "...TOD undertakings in these areas are often doubly challenged - they must overcome local zoning codes and surrounding land uses that favor the automobile while struggling to revive sometimes moribund realestate markets" (Cervero et al. 2004, p. 419). Planning for TOD should encompass a realistic assessment of local conditions, including economic feasibilities, although as demonstrated in Los Angeles, this does not always occur. Fortunately for TOD in Los Angeles, the recently constructed Gold Line from downtown Pasadena to Los Angeles has proven to be more successful.

\section{New Jersey}

New Jersey is a leader in smart growth and TOD policy. According to the Office of Smart Growth, the state traces its policies to 1934 when Governor Moore appointed a temporary planning board and the first state planning act was passed. ${ }^{6}$ Contemporary policies for growth management have stemmed from the 1970s, when Governor Byrne established the Governor's Office of Policy and Planning, and from 1986, when Governor Kean signed into law the State Planning Act creating the State Planning Commission and the Office of State Planning (renamed the Office of Smart Growth in 2002).

Table 6 describes some of the key smart growth policies in New Jersey. New Jersey has provided incentives for expanded employer-based commuting alternatives, the preservation of rural lands, and the transfer of development rights (TDRs). Plans in the Garden State have sought to gain "cross acceptance," a process whereby municipalities, counties, and the state reconcile goals and objectives within the State Plan. The State Plan must address land use, housing, economic 


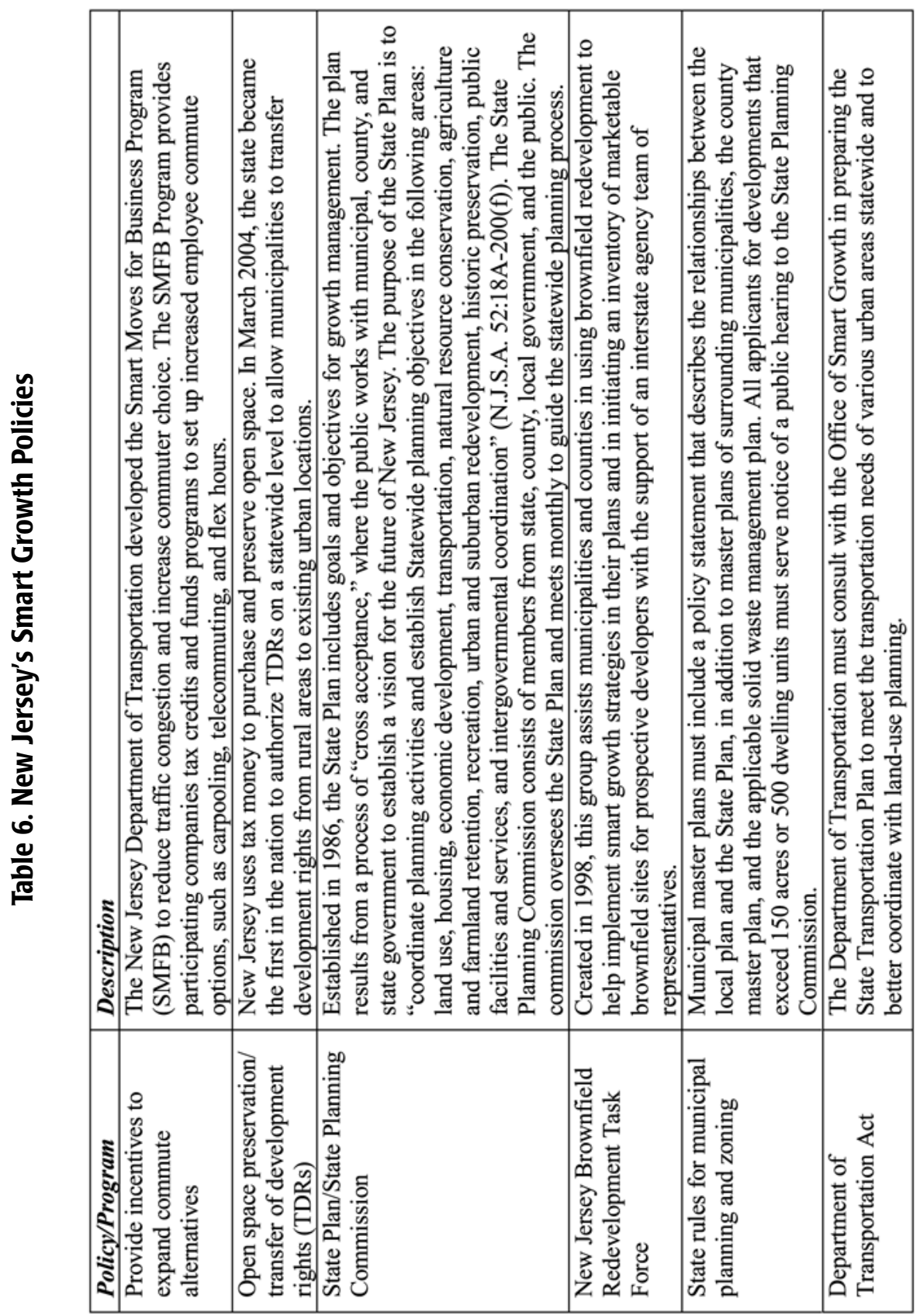




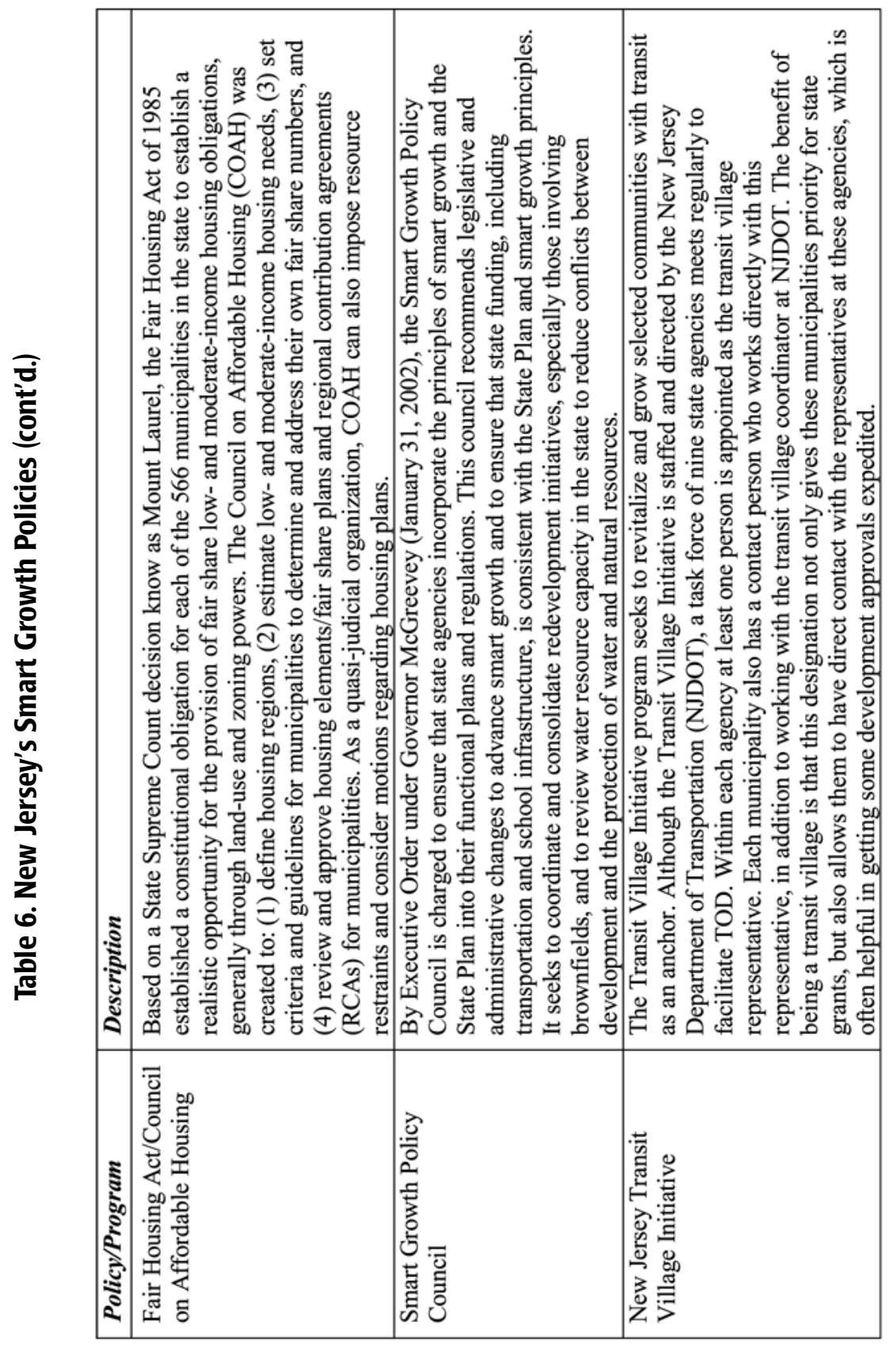


development, transportation, natural resource conservation, agricultural retention, recreation, redevelopment, historic preservation, intergovernmental coordination and public facilities and services. The State Planning Commission is an intergovernmental body, including members from the public, which oversees the plan through monthly meetings to guide the New Jersey planning process.

A number of other policies and initiatives have been tied into the state's planning process. The Brownfield Redevelopment Task Force is a state intraagency group that has assisted counties and local governments in redeveloping brownfields, which has helped to spur redevelopment. The State's Municipal Planning and Zoning law has mandated that municipalities establish a policy statement about how their local plan relates to the State Plan, the county master plan, and the plans of surrounding local governments. It also requires that any development exceeding 150 acres or 500 dwelling units must notify the State Planning Commission and hold a public meeting.

The Department of Transportation Act, enacted in 1992, mandated that the New Jersey Department of Transportation consult with the Office of Smart Growth in coordinating transportation infrastructure with statewide land-use planning. In 2002, under Executive Order by Governor McGreevey, the Smart Growth Policy Council was established to ensure that all state agencies incorporate smart growth principles into their functional plans and regulations. It also sought to advance smart growth planning via legislation and administrative changes in transportation, new schools, and brownfields.

Transit-oriented development in New Jersey is an old concept revived under new circumstances. Originally, commuter-rail suburbs built along a vast rail network serving New York City and Philadelphia allowed for the first generation of TODs in the Garden State. This lifestyle enabled people to escape living in the city while still accessing employment in urban centers. New Jersey has become the most urbanized state in America, and one of the wealthiest (in terms of income per capita). Its strategic location on the Northeast Corridor, between New York City and Philadelphia, has produced a strong job base for the state; however, New Jersey is not entirely reliant on these two metropolises. Many employment opportunities within the state have emerged, however, vast amount of jobs in the suburbs have led to deplorable traffic congestion. TODs (otherwise known in New Jersey as transit villages) offer residents an escape from congestion, but this time they have been returning from suburbia to traditional historic downtowns (as shown in Figure 3). 


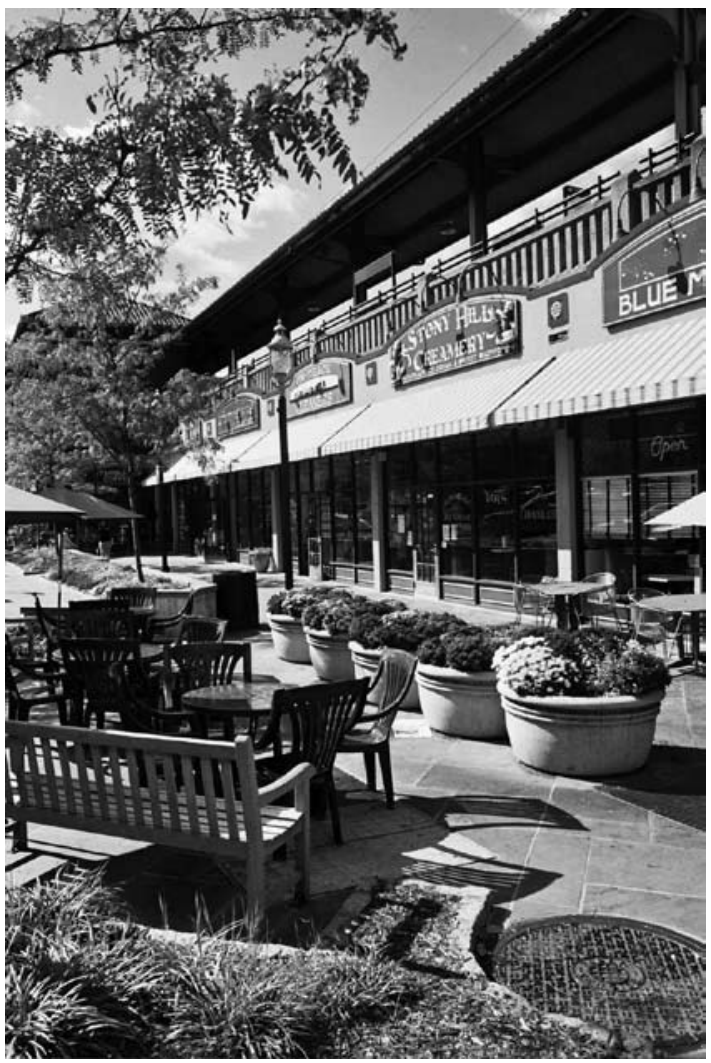

Figure 3. Retail Below the Train Station in the South Orange Transit Village

\section{The New Jersey Transit Village Initiative}

Established in 1999 by Governor Whitman, the New Jersey Transit Village Initiative is an interagency state program that promotes TOD. Today, there are 19 designated transit villages. Each transit village municipality works directly with the state government to promote compact mixed-use housing and economic development around its station. The New Jersey Department of Transportation (NJDOT) provides staff, directs the program, and manages a task force consisting of multiple state agencies that govern the initiative. In addition to the NJDOT, the Transit Village Initiative Task Force includes representatives from the following agencies: New Jersey Transit, Department of Environmental Protection (DEP), New Jersey Redevelopment Authority (NJRA), Department of Community Affairs (DCA; including representatives from the Office of Smart Growth and Main Street 
New Jersey), Economic Development Authority, Housing and Mortgage Finance Agency (HMFA), Commerce and Economic Growth Commission, and New Jersey Council on the Arts.

Members of the task force work directly with representatives from the local governments. Often, developers need approval from various state agencies, such as site remediation from the DEP or traffic impact from the NJDOT. Task force representatives, as well as the transit village coordinator from the NJDOT, work with local officials to expedite the development application approval process. Another benefit of being a transit village includes receiving preferential consideration for state grants. Transit villages also receive free technical assistance on planning and development issues. Each year, representatives from transit villages are invited to a forum where experts help local planners and officials overcome TOD implementation obstacles. However, local transit village contacts are encouraged to call on task force members for assistance anytime during the year. This "direct line" between the state and local government makes the Transit Village Initiative unique when compared to other TOD programs in the United States.

For transit village designation, a municipality must meet specified criteria supporting TOD when applying to the state. Applications are accepted during defined periods as dictated by the task force in conjunction with the governor's office. According to the NJDOT, local governments interested in becoming a transit village must commit in writing to growth in housing, jobs, and population. They must have a train, ferry, or major bus station, and meet a number of smart growth criteria, including an "adopted land-use strategy for achieving compact, transitsupportive, mixed-use development within walking distance of transit. This can be in the form of a redevelopment plan, zoning ordinance, master plan or overlay zone" (New Jersey Department of Transportation 2005). Other criteria include having vacant land near the station and a pedestrian- and bicycling-friendly urban environment.

The Alan M. Voorhees Transportation Center at Rutgers has been evaluating the success of the New Jersey Transit Village Initiative since 2002. This includes both process- and outcomes-based research. All of the reports, some of which have been written by this author, are available on the Alan M. Voorhees Transportation Center's website.? 


\section{Western Australia}

Hope for the Future: The Western Australian State Sustainability Strategy (Government of Western Australia 2003) discusses the need to manage urban and regional growth, revitalizing declining centers and suburbs, and integrating land use with balanced transport. The State Government of Western Australia also encourages TOD in Network City: Community Planning Strategy for Perth and Peel (Government of Western Australia 2004). The public identified TOD as a key factor in managing future growth as part of the Dialogue with the City outreach effort. Forecasts predict a growth in the region from 1.46 million people in 2001 to about 2.22 million by 2031 .

The priority strategies of the Network City Action Plan seek to foster land use and transport integration to form a network city: a city based on a series of interconnected TODs. The plan aims to limit urban sprawl by providing 60 percent of required additional dwellings in existing urban areas and 40 percent in new growth areas. To achieve this goal, a holistic governmental approach will be required, including partnerships between the state and local government to set and achieve targets.

Town planning in Western Australia comprises strategic and statutory planning. Network City sets the strategic vision for the region. Also dealing with strategic planning, the TOD committee, formed in 2004 and chaired by the Department for Planning and Infrastructure (DPI), has members representing the Public Transport Authority (PTA), TransPerth, Department of Housing and Works, Main Roads WA, Midland Redevelopment Authority, East Perth Redevelopment Authority, ${ }^{8}$ LandCorp, and the Western Australian Local Government Association. This cross-agency group replaced the Urban Rail Station Redevelopment Coordinating Committee, formed at the request of the Minister for Planning and Infrastructure in 2001. The role of the earlier committee was to provide a planning context for the PTA's Building Better Stations capital works program. Since inception, the TOD committee has reviewed the TOD potential of every station on the network (including major bus-only centers) and prioritized TOD activity in accordance with the following six criteria:

1. Strategic significance of location (i.e., metro centers, university, or hospital)

2. Potential for maximizing ridership, through increased catchment of residential, business, or park and ride 
3. Infrastructure need (i.e., station or road upgrades)

4. Potential for socioeconomic benefits (i.e., community activity, public safety, jobs)

5. Partnership potential (i.e., local government or private sector willingness)

6. Development opportunities (i.e., significant public or private land parcels adjacent and potential number of dwellings)

The TOD committee has also established joint priorities across the agencies (and other parts of government) for infrastructure investment and TOD development. Having formed a close association with the Planning and Transport Research Centre of Western Australia to research and measure the effectiveness of TOD initiatives, the committee has instigated a program to review priorities regularly and to refine the selection criteria and future success measures. The committee has identified land to acquire through the Western Australian Planning Commission (WAPC) to protect future TOD opportunities particularly around the new South West Metro rail line. They have also reviewed Development Control Policy DC 1.6-Planning to Support Transit Use and Transit Oriented Development, a statutory mechanism to encourage TOD across Perth. Finally, the TOD committee is developing two tools: an assessment framework for prioritizing which stations should receive investment and redevelopment and a monitoring method, under development by this author, to gauge the success of TOD using a sustainability framework based on travel behavior; local economy; the natural, built, and social environments; and the policy context.

Statutory planning for TOD, as mentioned, is governed by Development Control Policy DC 1.6, which has the following objectives:

- To promote public transport as an alternative to car travel and enhance mobility in the community, particularly for those who do not have access to a car.

- To ensure the optimum use of land close to railway stations, bus terminals, transport interchanges and corridors containing frequent public transport services for residential, commercial and other intensive uses.

- To maximize accessibility to rail and other public transport services, in particular high-frequency bus routes.

- To maximize accessibility by rail and other public transport to a range of work, shopping, and other urban activities. 
- To facilitate safe pedestrian and cycle access to and from public transport services and a range of activities focused around them.

- To promote the development of a more sustainable urban form.

- To promote designs for public transport that minimize any adverse impact on local amenity arising from public transport operations.

- To ensure adequate consideration is given to public transport access by planning authorities, consultants, and developers.

With respect to TOD, DC 1.6 is one of the most innovative policies ever written across Australia and the United States. It spells out, albeit in general terms, the need for local government to plan for high-density and mixed-use development around major transport nodes. DC 1.6 encourages mixed land uses within strategic regional centers, especially major office development, major retail facilities, high-density housing, sporting stadiums, and major entertainment venues. It also encourages increased residential densities and commercial and mixed uses within the TOD precinct of all major public transport infrastructure nodes. It specifies that medium- to high-density residential development should accommodate groups that are dependent on public transport, such as the elderly, the socioeconomically disadvantaged, and those with disabilities. The policy also encourages uses that allow for retail and office space and recreational, educational, and entertainment activities within TODs (as shown in Figure 4). The policy specifies against low-intensity commercial uses, such as showrooms and warehouses; low-density residential, public utilities, and drainage reserves; and large areas of undeveloped public open space in areas where TOD would be appropriate.

DC 1.6 specifically calls for higher residential densities and reduced car parking provisions in town planning schemes ${ }^{9}$ to encourage walking, cycling, and use of public transport. It recommends the implementation of TOD through the update of town planning schemes. Local governments are required to update their town planning scheme once every five years, and through this process the WAPC, which uses DC 1.6 to guide its decisions, may encourage them to plan for higher density and mixed-use development. DC 1.6 also calls for a pedestrian-friendly, attractive urban environment with safe streets that have buildings adjacent to sidewalks, quality sidewalk design, and safe at-grade pedestrian crossings. DC 1.6 also encourages the adoption of design standards in which the built environment contains shade trees, verandas, and pedestrian amenities. Street networks should be interconnected and accessible within TODs and include a number of "destinations" such as cafés and neighborhood centers. 


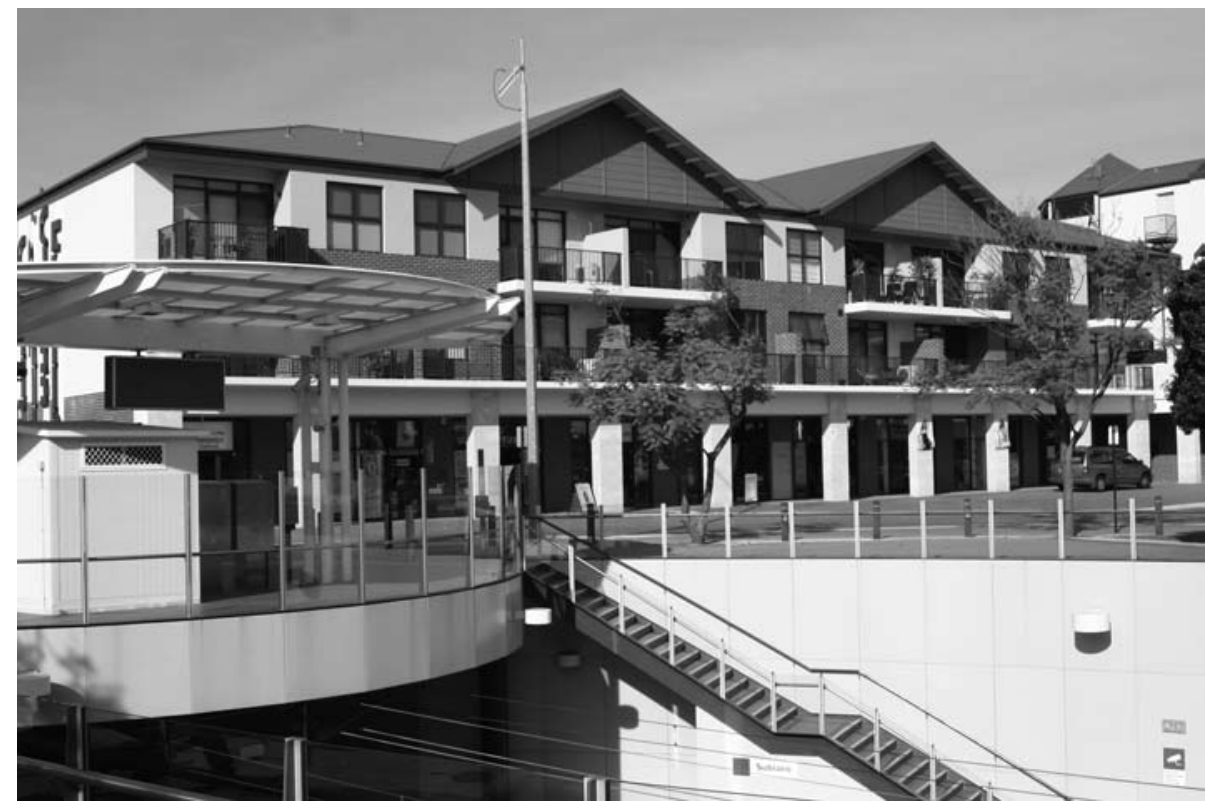

Figure 4. Mixed Use Development above the Subiaco Train Station

In addition to DC 1.6, a number of other policies also encourage the integration of land use and transport planning with the aim of achieving more compact and mixed-use development in Western Australia. The Metropolitan Region Scheme (MRS) identifies reserves for future rights-of-way. The Metropolitan Centres policy identifies a hierarchy of locations for retail and commercial development at regional and district centers.

Curtis (1999) concluded that Western Australia has innovative policies that work toward an integrated land use and transport system, but that these were not supported by a uniform policy described in a central document. It could be argued that the Network City is attempting to achieve this, but until a plan for implementation is released, this will remain uncertain.

The problem for TOD today is the same problem that Curtis identified in 1999: "There appears to be a misalignment between strategies and actions, with little evidence of implementation that achieves balanced transport outcomes" (p. 349). The successes of redevelopment authorities in places like Midland and Subiaco unfortunately affect only a small percentage of new development, most of which is low density and automobile dependent. While Perth has a history of planning, 
much of it has perpetuated a car culture. The Network City's goal of 60 percent infill development over the next 30 years will require substantial cooperation among the state government, local government, community, and private sector if TOD is to become more than a niche development product.

A study published by this author in 2005 looked at TOD attitudes, obstacles, and opportunities in Perth. The research included a survey of all local governments with train stations in Perth, as well as 37 interviews with stakeholders from both the public and private sector. While the findings suggested the market for TOD has been strong and growing, one of the biggest obstacles for the private sector is that every new TOD requires reinventing the wheel. Developers often experience longer-than-usual delays through the development approval process compared to typical suburban developments. A lack of awareness and training among public employees responsible for various aspects of implementation was also identified as a problem. The report identified 10 recommendations for TOD in Western Australia:

1. Better marketing and branding for TOD.

2. A central transport and land-use strategy with targets.

3. A TOD code to guide the statutory planning process in TODs, including parking policy.

4. Community participation in local visioning processes and the streamlining of development applications where they conform with the local TOD vision.

5. Local and state government partnerships for TOD implementation.

6. A financing strategy, including an income stream to assist transit investment and land assembly.

7. State government facilitation of TOD education.

8. A plan for affordable housing.

9. Linking TOD to the development of new education, health, and other public buildings.

10. A plan for tracking TOD outcomes (Renne 2005).

\section{Conclusion}

TOD planning in California, New Jersey, and Western Australia demonstrates similar but different approaches. As discussed earlier, it is important to remember that 
states do not typically have a role in land-use decisions. States control transportation infrastructure dollars and thus can coerce and provide incentives to locals for "doing it right." The role of MPOs was not addressed much in this article and more research is needed to determine if states would be better off passing money to MPOs to create programs like the TLC and HIP in the Bay Area. Even if states choose to activate MPOs more in planning for TOD, there is still an important role for state government in setting a policy framework for communication across state agencies and among lower levels of government in planning for TOD.

Although California took a legislative approach in the 1990s through the adoption of the Transit Village Development Planning Act, the lack of financial support resulted in virtually no impact. Several non-TOD-specific tools have been useful, particularly the state treasurer's decision to use a point-based system in allocating affordable housing tax credits, which has resulted in more nonprofit housing developers locating developments in TODs. The 2002 California-sponsored study demonstrated the main role of the state government-providing leadership, research, technical expertise, and a nexus for coordinating TOD at both the local and regional levels.

The state's role in New Jersey, while different from California, has produced similar results. While the New Jersey Transit Village Initiative provides a little more funding specifically for transit villages, as well as technical expertise for designated municipalities, the ultimate boon has been the hype of the program among local government and developers. Local governments want the credibility to call themselves transit villages and developers with TOD expertise are beginning to focus on those communities. The transit village designation is a signal to the private sector that compact, mixed-use development is welcomed and encouraged. Smart growth advocates are increasingly at odds with locally NIMBYs who are unwilling to accept any growth. The Transit Village Initiative in New Jersey is a model for local and state partnership to create smart growth zones, otherwise known as transit villages, where developers can focus their attention.

The model in Western Australia is similar to the one in New Jersey. Despite a different political system, one which ultimately gives state government more planning powers, local governments across Perth have a major say in land-use decisions. Although the state can override local decisions, this rarely happens. The state TOD committee in Western Australia has been a forum for moving TOD planning and implementation forward. The committee coordinates capital investment, government policy, and implementation strategy. 


\section{Model State TOD Program}

Given the best practice examples of California, New Jersey, and Western Australia, this section presents a model state TOD program. Regions looking to implement TODs should collaborate with their state government to establish a committee that brings together stakeholders from various state agencies, MPOs, transit agencies, and local government. The following 10 actions are important to any state looking to encourage TOD:

1. Establish a committee that meets on a monthly or quarterly basis.

2. Ensure intrastate agency participation, including agencies that deal with transportation, housing, the environment, economic development, and any others that have a stake in smart growth.

3. Ensure intergovernmental participation, including MPOs and municipal government.

4. Ensure transit provider participation.

5. Ensure participation from the affordable housing sector.

6. Establish short- and long-term goals that will drive a work plan.

7. Establish clear goals and objectives so local government and developers know what to expect.

8. Use the committee to coordinate capital investments to reinforce success.

9. Use marketing and branding to sell a lifestyle choice.

10. Monitor outcomes and continually update goals and objectives.

In a classic debate about smart growth in the Journal of the American Planning Association, Reid Ewing stated, "My answer to sprawl is active planning of the type practiced everywhere except the United States..." (Ewing 1997, p. 118). Active planning means participation among various agencies, governments, and stakeholders. TOD initiatives in California, New Jersey, and Western Australia demonstrate the importance of a collaborative approach-one that should be considered by any state looking to manage growth. 


\section{Endnotes}

${ }^{1}$ DPI contains Main Roads WA, Western Australia's DOT equivalent.

${ }^{2}$ No single source, including the U.S. EPA database, was found that accurately reported all state-level smart growth policies. Data presented in this article was compiled from a variety of sources and to the best of the author's knowledge it represents an accurate inventory, although new policies are continually emerging.

${ }^{3}$ In the early 1990s redevelopment legislation in California was strengthened to ensure that such zones were actually located in a blighted area because redevelopment zones place a greater tax burden on the state government.

${ }^{4}$ The MTA is Los Angeles's regional transit agency.

${ }^{5}$ For more information on the Blue Line's failure with respect to TOD, read "The Blue Line Blues: Why the Vision of Transit Village May Not Materialize Despite Impressive Growth in Transit Ridership" by Loukaitou-Sideris and Banerjee in the Journal of Urban Design (2000) 5, 2: 101-125.

${ }^{6}$ A chronology of planning policy can be found at: http://www.nj.gov/dca/osg/ smart/chronology.shtml.

${ }^{7}$ http://www.policy.rutgers.edu/vtc/tod/tod_projects.html.

${ }^{8}$ The Midland and East Perth Redevelopment Authorities have been created by the state government of Western Australia to encourage infill development and TOD.

${ }^{9}$ Town planning schemes in Western Australia are initiated by local government and approved by the Minister for Planning and Infrastructure based on a recommendation of the WAPC. They become the statutory planning regulation that governs development applications.

\section{References}

All aboard! 2006. The Economist.

Bureau of Transport and Regional Economics. 2003. State spending on roads Commonwealth of Australia. 
California Department of Transportation. 2002a. Statewide transit-oriented development study: Factors for success in California. Sacramento: California Department of Transportation.

California Department of Transportation. 2002b. Statewide transit-oriented development study: Factors for success in California-technical appendix. Sacramento: California Department of Transportation.

California State Treasurer. 2001. The Double Bottom Line: Investing in California's Emerging Markets. California State Treasurer, Sacramento, California.

Cambridge Systematics. 2006. The role of state DOTs in support of transit-oriented development. Project 25-25, Task 20 National Cooperative Highway Research Program, Transportation Research Board, Washington, DC.

Center for Transit-Oriented Development. 2004. Hidden in plain sight: Capturing the demand for housing near transit. Las Vegas, NM: Reconnecting America.

Cervero, R. 1994. Transit-based housing in California: Evidence on ridership impacts. Transport Policy 1,3: 174-183.

Cervero, R. 1998. Transit villages in California: Progress, prospects, and policy reforms. Berkeley, CA: Institute of Urban and Regional Development, University of California at Berkeley.

Cervero, R., G. B. Arrington, J. Smith-Heimer, R. Dunphy, S. Murphy, C. Ferrell, N. Goguts, Y.-H. Tsai, J. Boroski, R. Golem, P. Peninger, E. Nakajima, E. Chui, M. Meyers, S. McKay, and N. Witenstein. 2004. Transit-oriented development in America: Experiences, challenges, and prospects. TCRP Report 102. Washington, DC: National Academy Press.

Curtis, C. 1999. Turning strategies into actions-Integrated land use and transport planning in Western Australia. 23rd Australasian Transport Research Forum, Perth, Western Australia. September 29-October 1, 1999, pp. 349-363.

Dittmar, H., and G. Ohland. 2004. The new transit town: Best practices in transitoriented development. Washington, DC: Island Press.

Dunphy, R., R. Cervero, F. Dock, M. McAvey, and D. Porter. 2004. Developing around transit: strategies and solutions that work. Washington, DC: Urban Land Institute.

Ewing, R. 1997. Is Los Angeles-Style sprawl desirable? Journal of the American Planning Association 63:107-126. 
Government of Western Australia. 2003. Hope for the future: The Western Australian state sustainability strategy. Perth: Department of the Premier and Cabinet.

Government of Western Australia. 2004. Network city: Community planning strategy for Perth and Peel. Perth: Western Australian Planning Commission.

Hersh, L. 2001. The role of state government in transit-oriented development. Philadelphia: Pennsylvania Environmental Defense Council.

Johnson, D., P. E. Salkin, and J. Jordan. 2002. Planning for smart growth: 2002 State of the states. Chicago: American Planning Association.

Kenworthy, J. and F. Laube. 2001. Millennium cities database. Brussels: International Association of Public Transport.

Levine, J. 2006. Zoned out: Regulation, markets, and choices in transportation and metropolitan land-use. Washington, DC: Resources for the Future.

Levine, J., and A. Inam. 2004. The market for transportation-land use integration: Do developers want smarter growth than regulations allow? Transportation 31: 409-427.

Lund, H., R. Cervero, and R. Wilson. 2004. Travel characteristics of transit-oriented development in California. Sacramento: Caltrans Statewide Planning Studies.

McGreevey, G. J. 2002. Executive Order \# 4: Smart Growth Policy Council [Online] http://www.state.nj.us/infobank/circular/eoindex.htm\#mcgreevey.

Metropolitan Transportation Commission. 2004. Transportation for livable communities capital program: Draft recommended program of projects. Metropolitan Transportation Commission, Oakland, CA.

New Jersey Department of Community Affairs. 2005. Office of Smart Growth [Online] http://www.nj.gov/dca/osg.

New Jersey Department of Transportation. 2005. Transit Village Initiative Website [Online] http://www.state.nj.us/transportation/community/village/.

Newman, P. 2005. Transit oriented development: An Australian overview. Proceedings from Transit Oriented Development: Making It Happen, Planning and Transport Research Centre, Fremantle, Western Australia, July 5-8, 2005. http://www.patrec.org/conferences/TODJuly2005/TODJuly2005.html. 
Newman. P., and J. Kenworthy. 1999. Sustainability and cities: Overcoming automobile dependence. Washington, DC: Island Press.

Renne, J. 2005. Transit-oriented development in Western Australia: Attitudes, obstacles, and opportunities. Perth, Western Australia: Planning and Transport Research Centre.

Shoemaker, D. 2004. Personal interview.

Urban Land Institute and PricewaterhouseCoopers. 2005. Emerging trends in real estate 2005. Washington, DC: Urban Land Institute.

Urban Land Institute and PricewaterhouseCoopers. 2006. Emerging trends in real estate 2006. Washington, DC: Urban Land Institute.

U.S. Environmental Protection Agency. 2005. Smart Growth Policy Database [Online] http://cfpub.epa.gov/sgpdb/sgdb.cfm. Available from U.S. Environmental Protection Agency.

\section{About the Author}

JoHN L. ReNNe (jrenne@uno.edu) is an assistant professor of urban planning and transportation studies at the University of New Orleans. He is also an associate director of the university's Transportation Center. His research focuses on land-use and transportation planning in the United States and Australia. He is affiliated with the Planning and Transport Research Centre of Western Australia and the Institute for Sustainability and Technology Policy in Western Australia. 